\title{
Analysis of leaks from geomembrane in a sanitary landfill through models of electrical resistivity tomography in South Brazil
}

\author{
César Augusto Moreira ${ }^{1} \cdot$ Lívia Portes Innocenti Helene ${ }^{2} \cdot$ Paulo Nogara $^{3} \cdot$ Lenon Melo llha $^{4}$
}

Received: 19 April 2017 / Accepted: 16 December 2017 / Published online: 22 December 2017

c) Springer-Verlag GmbH Germany, part of Springer Nature 2017

\begin{abstract}
Landfills are the main destination of solid waste generated in Brazil. Based on technical criteria, the construction of a landfill aims to minimize environmental impacts since it can present problems of high complexity. This paper discusses the use of electric resistivity tomography applied in a waste cell of a landfill, and its objective is to evaluate the effectiveness of such tool in the detection of possible leachate's leakage points in the landfill's geomembrane. The leachate is a liquid effluent characterized by a high content of dissolved salts produced by the decomposition of organic matter. Therefore, a signature of low electrical resistivity defines the presence of this compound in soil and groundwater. The analysis of 12 sections of electrical resistivity tomography in Schlumberger arrangement allowed the estimation of $47 \Omega \mathrm{m}$ as the minimum resistivity value for the natural conditions, in addition to the possibility to provide the identification of the area under the waste cell with lower resistivity values. The integration of a software that compiles $2 \mathrm{D}$ data into $3 \mathrm{D}$ viewing models enabled isosurface adjustments of 7 and $14 \Omega \mathrm{m}$ in resistivity maps to -4 and $-10 \mathrm{~m}$ depth levels at the base of the landfill and the aquifer, respectively. These areas define points of infiltration in soil, by leakage at geomembrane in the bottom of the landfill. The results show the applicability of the method in the diagnosis of leachate contamination in a high-complexity environment. In addition, it is possible to establish an effective system for the remediation in a place where the installation of monitoring wells can increase the environmental impact.
\end{abstract}

Keywords Landfill $\cdot$ Leachate $\cdot$ Leakage $\cdot$ Electrical resistivity $\cdot$ 3D modeling

\section{Introduction}

Landfills are the main destination of solid waste collected from homes, industry, and commerce in Brazil, with a volume of approximately 78 million tons in 2014 . The generation of solid waste has increased more than $2.9 \%$ since 2003 , which is extremely worrying in comparison with a rate of

César Augusto Moreira

moreirac@rc.unesp.br

Lívia Portes Innocenti Helene

liviapihelene@gmail.com

Paulo Nogara

prznogara@hotmail.com

Lenon Melo Ilha

lmgeofisik@hotmail.com

1 Department of Applied Geology (DGA), Geosciences and Exact Sciences Institute (IGCE), University Estadual Paulista (UNESP), 24-A avenue, 1515, Bela Vista, Rio Claro, São Paulo State 13506-900, Brazil population growth of $0.9 \%$ in the same period (ABRELPE 2014).

Since 2003, there has been an increase in the degree of schooling, low-interest credit availability for a large part of the population, and income distribution policies geared to needy families through scholarships and various social programs. These factors allowed an increase in purchasing

2 Post-Graduate program in Geosciences and Environmental Science, Geosciences and Exact Sciences Institute (IGCE), University Estadual Paulista (UNESP), 24-A avenue, 1515, Bela Vista, Rio Claro, São Paulo State 13506-900, Brazil

3 Post-Graduate program in Applied Geophysics in Mineral Exploration and Environment, University Federal do Pampa (UNIPAMPA), Pedro Anunciação avenue, 111, Batista Ville, Caçapava do Sul, Rio Grande do Sul State 96570-000, Brazil

4 University Federal do Pampa (UNIPAMPA), Pedro Anunciação avenue, 111, Batista Ville, Caçapava do Sul, Rio Grande do Sul State 96570-000, Brazil 
power coupled with a sophisticated system of selective marketing campaigns, which resulted in a change of consumption patterns. The possibility of purchasing products beyond their immediate need culminated in substantial changes in consumption habits of a significant part of the Brazilian population.

The federal legislation that regulates the management of solid waste in Brazil is Law $\mathrm{n}^{\circ} 11.445$ of 2007, also named National Politics for Basic Sanitation (Brasil 2007), which states that solid waste must integrate the municipal plans for sanitation, and Law $n^{\circ} 12.305$ of 2010, named National Politics for Solid Waste (Brasil 2010).

The organic waste generated in residences represents more than $50 \%$ of the total collected, with a maximum of 3\% used for composting (Cempre 2013; Jacobi and Besen 2011). The majority of solid waste in Brazil is disposed in sanitary landfills (59\%) or controlled landfill dumps (41\%), whose collection and management are the responsibility of the Municipalities (SNIS 2013).

Controlled landfills are the ones based on minimum technical criteria for its operation and construction. On the other hand, sanitary landfills are well-planned systems for throwing and compacting waste in cells. Their construction must have basal waterproofing membranes, adequate basal slope for the gravitational flow of effluent liquids, collection systems for gases and leachate, geotechnical stability and monitoring systems for groundwater (Christensen 2011; Reddy 2011; Deublein and Steinhauser 2011).

Although planned with a series of technical criteria, there are many problems encountered in landfills: direct release of greenhouse gas emissions (methane), problems in the drainage and treatment of leachate, geotechnical instability, insufficient coverage of the soil, excessive hold, erosion of coverage soil, slipping of residues, among others (Yung-Tse et al. 2014; Pawlowska 2014).

A problem of major environmental impact is the contamination of the aquifer by the leachate due to drilling or incorrect installation of the geomembrane. In many cases, the detection of the problem is during the operational phase of the landfill, essentially by means of monitoring wells planned and installed exactly for this purpose. However, the wells do not allow detecting the point of infiltration with accuracy (Lehr et al. 2001; Sara 2003; Twardowska et al. 2006; Bhandari et al. 2007; Hernandez-Soriano 2014; Berkowitz et al. 2014).

The application of indirect subsurface research methods, in complex situations of soil and groundwater contamination, can be a versatile and low-risk evaluation alternative, and allows for an adequate diagnosis for planning actions to contain the polluting sources and remediate the area.

Electrical geophysical methods are widely used in environmental and hydrogeological studies due to the sensitivity of the instrumental to measure changes in physical parameters intrinsic to the geological environment. The natural contrast enables the detection of cavities, recognition of directions and workflow structures, estimation of hydraulic properties, and the presence of contaminants in soil and groundwater.

Electrical resistivity tomography, in particular, is widely used in the detection of contaminants in subsurface because it is a technique that produces a spatialized and in-depth result, which is very convenient for the identification and delimitation of contamination plumes.

From the process of leachate generation in landfills and its chemical composition, it is expected that the leachate's presence in soil and groundwater results in low resistivity values, essentially due to the high content of totally dissolved solids. Many studies prove the efficiency of the method in the identification of leachate in the subsurface (Valdelet et al. 2011; Belmonte et al. 2012; Genelle et al. 2012; Elijah and Oluwatosin 2015; Maurya et al. 2017; Dono and Cardarelli 2017).

This paper presents the results of the application of electrical resistivity tomography in a landfill-disabled cell of solid waste, as an attempt to determinate leakage points in the geomembrane, in addition to soil and groundwater contamination.

\section{Study area}

The municipality of Vila Nova do Sul is located in the central-south region of Rio Grande do Sul state (RS) (Fig. 1), bordering the municipalities of Caçapava do Sul, São Sepé and São Gabriel, approximately $280 \mathrm{~km}$ away from Porto Alegre, the state's capital. Vila Nova do Sul's population is around 4421 inhabitants and its economy consists in agriculture, mining, commerce, and services.

The municipal administration finances the collection of the municipal solid waste and is responsible for the transport of approximately 130 tons of waste per month. This landfill has an area of $44.650 \mathrm{~m}^{2}$ and is located about $4 \mathrm{~km}$ north of the municipality's administration. It currently has two wastes cells: one exhausted and another in construction phase.

The exhausted cell has approximately $4 \mathrm{~m}$ of depth. The soil that is used to the daily covering of the waste came from the excavation of the cell during its opening. The base of the cell has been covered by a waterproofed geomembrane and has a leachate collection system that transports, by a gravitational pipeline, the leachate to a couple of tanks located downstream. The groundwater level on site is at $10 \mathrm{~m}$ of depth, with direction flow to southeast.

Chemical analysis in groundwater samples colleted in the monitoring wells localized in downstream of the groundwater flow (Fig. 1) indicated high salinity, by the presence of chlorate $(25.8 \mathrm{mg} / \mathrm{L})$, total nitrogen $(3.07 \mathrm{mg} \mathrm{N} / \mathrm{L})$, high 
Fig. 1 Location and constructive aspects of the study area

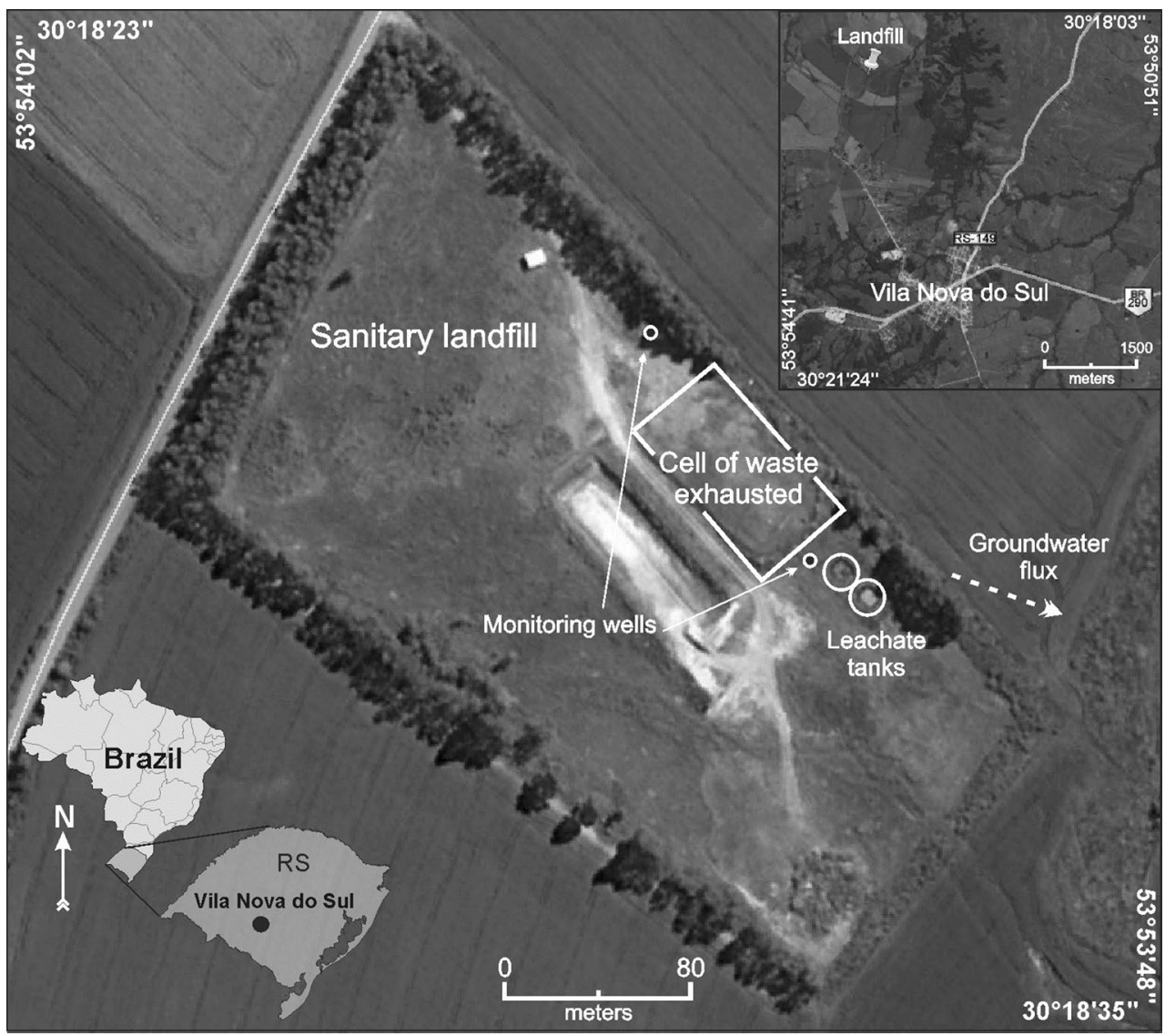

biochemical oxygen demand (BOD) (99.5 $\left.\mathrm{mg} \mathrm{O}_{2} / \mathrm{L}\right)$, and acidity, with $\mathrm{pH} 5.04$.

The climate of the region is of the type Cfa, characterized like rainy, with a cold winter and hot summer and with precipitations rates distributed throughout the year. The annual average rainfall values vary between 1300 and $1600 \mathrm{~mm}$, in general, with slightly higher rates in the period from June to August. The average annual temperature varies between 16 and $19{ }^{\circ} \mathrm{C}$, with minimum averages between 12 and $13{ }^{\circ} \mathrm{C}$ in July and maximum averages between 29 and $31{ }^{\circ} \mathrm{C}$ in December (Porcher and Lopes 2000).

It is a small landfill located in a region of high rainfall, mainly in June and August. The chemical analyses of the wells, carried out in the rainy season by the municipal authorities, present diluted salt contents when compared to the typical values of young landfills. The present study was carried out about four months after the chemical analysis, a time interval that hinders eventual correlations between values of electrical resistivity and total dissolved solids.

The region presents a predominance of shallow and undeveloped clay soil, with a horizon A seated either on an unexpressive horizon $\mathrm{C}$ or directly on rock. The region is inserted in the Planalto Sul-Rio-Grande geomorphological unit, sculpted on the lithological units that compose the Sul-Rio-Grande Shield. The Planalto Marginal Rebaixado geomorphological unit is a dissected and lowered surface in relation to the high relief of residual plateaus, with altitudes ranging between 100 and $200 \mathrm{~m}$.

The geological context defined the local occurrence of gneisses from the Cambaí Complex (Porcher 2000). The dioritic gneisses, which apparently are the dominant rocks west of Vila Nova do Sul, below the study area, are dark gray in color, with average granulation and often present a banding marked by fine quartz feldspar levels. They are predominantly comprised of plagioclase, biotite and/or hornblende and quartz. The Cambaí Gneisses are chemically characterized as of low alkaline calcium affinity; they are submitted to higher metamorphic degrees of amphibolite and green schist facies retrogressive.

\section{Materials and methods}

The geophysical survey consisted in 12 lines of electrical resistivity tomography with Schlumberger arrangement, $5 \mathrm{~m}$ spacing between electrodes and between lines, for electrical resistivity measurements at various depths of the layer of waste (Fig. 2). Each line was 95 meters long where 20 
Fig. 2 Localization of electrical resistivity tomography lines

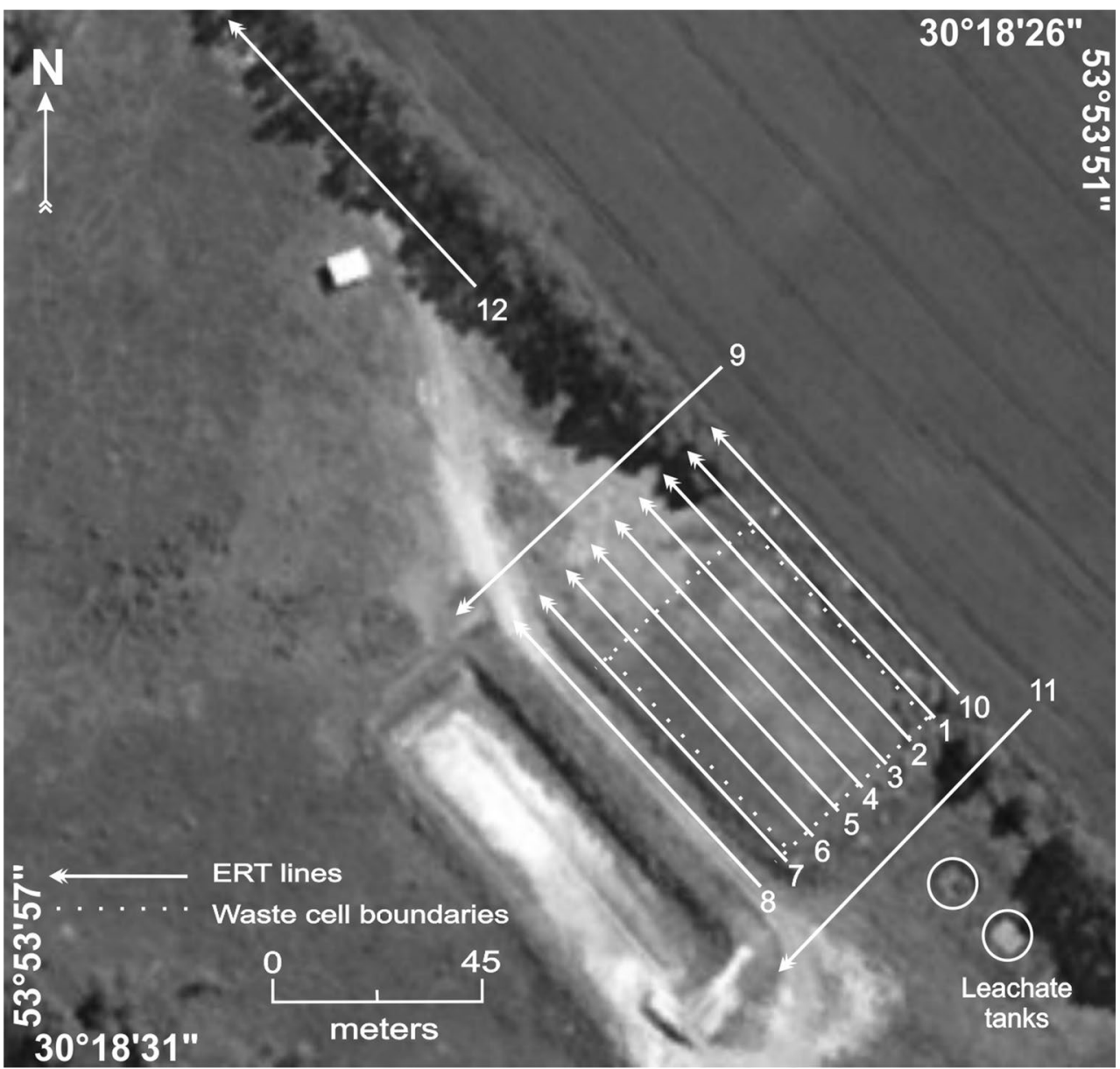

electrodes were arranged along with the current transmission cables.

Line 12 was held parallel to the road that gives access to the landfill, in the highest position of the area to obtain reference values and subsequent comparison with the other measures on the waste cell. Lines 8 and 10 were positioned in the external side of the waste cell. Line 9 was located parallel to the upper end and external to the cell, while line 11 was leased parallel to the lower and external end, with the objective of intercepting the groundwater flow from the waste cell. Lines 1 through 8 and line 10 were acquired in the opposite direction to groundwater flow, while lines 9 and 11 were arranged perpendicular to the underground flow.

The equipment used was the resistivity meter Terrameter LS, manufactured by ABEM Instrument (Sweden), which consists of single module for transmission and reception of signals from automated prior programming, with $250 \mathrm{~W}$, resolution of $1 \mu \mathrm{V}$ and maximum current of $2.5 \mathrm{~A}$.

This equipment allows measurements of spontaneous potential (SP), electrical resistivity tomography (ERT) and induced polarization (IP) by means of periodic cycles of transmission and reception of signals, automatic calculation of the contact resistance and the standard deviation of the set of measures (ABEM 2012). The geophysical equipment automatically records the field data in internal memory, in the form of formatted spreadsheet that can be accessed via USB interface.

The parameters used during the acquisition were $300 \mathrm{~V}$ with time of measurement of $0.1 \mathrm{~s}$. The acquisition parameters allied to the electrode arrangement allowed 120 measurements per acquisition lines. The large amount of data and the arrangement allowed for a high-resolution detailing of the first layers, so the constructive aspect of the landfill could be noticed.

Although the acquisition line is $95 \mathrm{~m}$, the arrangement uses a set of four electrodes, with measurements taken at the center of the array; thus, the acquisition of the tomography data is obtained from $7.5 \mathrm{~m}$ and encloses within $87.5 \mathrm{~m}$, which results in a section with $81 \mathrm{~m}$ long, as presented further in the inversion models. More information about the electrode's arrangement and acquisition can be found in Milson and Erikssen (2011).

This investigation method by electrical resistivity tomography enables the identification of the natural contrast in the electrical properties between the subsurface geological materials and the presence of leachate. By this means, it is 
possible to identify indications of contamination in soil and groundwater under the waste cell.

The field measurements were initially processed with the software Res2Dinv, where, from the smoothed inversion method, bi-dimensional resistivity models for the subsurface were generated (Geotomo Software 2013). The sections are presented in terms of distance and depth, with logarithmic graphic scale and intervals of interpolation of values in color.

The method of inversion by smoothing uses the mathematical method of least squares, where the software recognizes the terrestrial subsurface as rectangular blocks that have constant values for the investigated parameter (Loke and Baker 1996). This optimization aims to reduce the difference between the apparent resistivity values, calculated and measured in the field, by adjusting the resistivity of the block model, with the difference expressed by the RMS error (Root Mean Squared) (Loke and Baker 1996).

After 2D inversion, the data were gathered in single file, later used as a database for generating 3D models maps and depth models. This process was developed in the Oasis Montaj platform, where the 2D data obtained with Res2Dinv were interpolated and modeled using the minimum curvature method for enhancement of the extreme values, in models of three-dimensional blocks, where the ERT lines were positioned.

Geophysical 3D pseudo-models generated from 2D sections provide a very wide comprehension of the complexity of geological and hydrogeological structures, especially at short distance between the acquisition lines and data (Chambers et al. 2006; Aizebeokhai et al. 2011; Moreira et al. 2016; Vieira et al. 2016; Côrtes et al. 2016).

\section{Results and discussion}

In addition to the physical-chemical characteristics of the products generated in this process, with emphasis in the main constituents of the leachate, the geophysical data analysis must consider some characteristics related to the degradation of organic matter in the landfills. That can guide the geophysical interpretation.

The formation and volume of the gas and liquid phases depends on the type of waste, rainfall, degree of infiltration in the landfill, and capacity to maintain humidity and compression levels of the waste, along with other factor such as age of landfill (Lema et al. 1988; Kulikowska and Klimiuk 2008).

Priority information on the construction aspects of the landfill, such as depth of geomembrane installation and the location of the disposal of the leachate collection system, also helped to determine the field methodology, such as spacing between electrodes and acquisition parameters, in order to favor the shallower depths.

The generation of inversion models in terms of electrical resistivity from the data collection consists in sections of depth and distance with resistivity values varying between 12.5 and $285 \Omega \mathrm{m}$. The most representative models were grouped in sets that enable comparisons with the reference section (line 12), performed at the access road to the area, upstream of the cell of waste (Fig. 3).

The reference line is characterized by homogeneity in high resistivity values (around $285 \Omega \mathrm{m}$ ), from the surface to approximately $-10 \mathrm{~m}$ of depth. In this range, it occurs in dry soil and an accentuated drop in values, indicative of the beginning of the local aquifer, with minimum values of $47.7 \Omega \mathrm{m}$, typical of free aquifers with clay matrix. The average resistivity of the aquifer is around $70 \Omega \mathrm{m}$

Sections 1, 2, 3, 4, 5, 6 and 7 were performed over the waste cell and show lower resistivity values than the natural minimum for the area. The spread of values between $47.7 \Omega \mathrm{m}$ (natural minimum) and $19.5 \Omega \mathrm{m}$ (sections minimum) defines the range of percolation of inorganic solutions, which in a geological environment, are responsible for the artificial reduction of electrical resistivity in soils and rocks. Consequently, the range of values above defines the presence of leachate from a leak in the geomembrane base of the waste cell.

Sections 10 and 8 were performed on the external side of the area, i.e., in the periphery of the waste cell. Section 10 presents a resistivity area of less than $47.7 \Omega \mathrm{m}$ between the $43 \mathrm{~m}$ and $55 \mathrm{~m}$ position on the surface and ends in groundwater level's depth (-10 m) (Fig. 3).

Section 9, performed in the northeast external lateral of the waste cell, presents a resistivity values around $280 \Omega \mathrm{m}$ from the surface up to $8 \mathrm{~m}$ of depth. Below $8 \mathrm{~m}$, there occur minimum resistivity values of $30.5 \Omega \mathrm{m}$, lower than the natural values for the area.

Section 11 was performed in the southeast external lateral of the waste cell, perpendicular to other lines and downstream of the groundwater flow, between the waste cell and the leachate tanks. This section presents resistivity values around $30.5 \Omega \mathrm{m}$ between 40 and $60 \mathrm{~m}$ positions (Fig. 3).

The lateral interpolation of the 2D inversion data from the electric tomography allowed the elaboration of a 3D block. Then, it is possible to identify an extensive volume of low resistivity values in the direction of the groundwater flow (Fig. 4).

The electric resistivity layer for the geomembrane level presents a high extension of values below $47.7 \Omega \mathrm{m}$, the limit between the natural resistivity of the aquifer, indicative of the presence of saline compounds (Fig. 4). In sequence, the $3 \mathrm{D}$ block was divided in layers to the depths of $-4 \mathrm{~m}$ the base of the waste cell where the geomembrane is positioned and $-10 \mathrm{~m}$, the local aquifer level. 


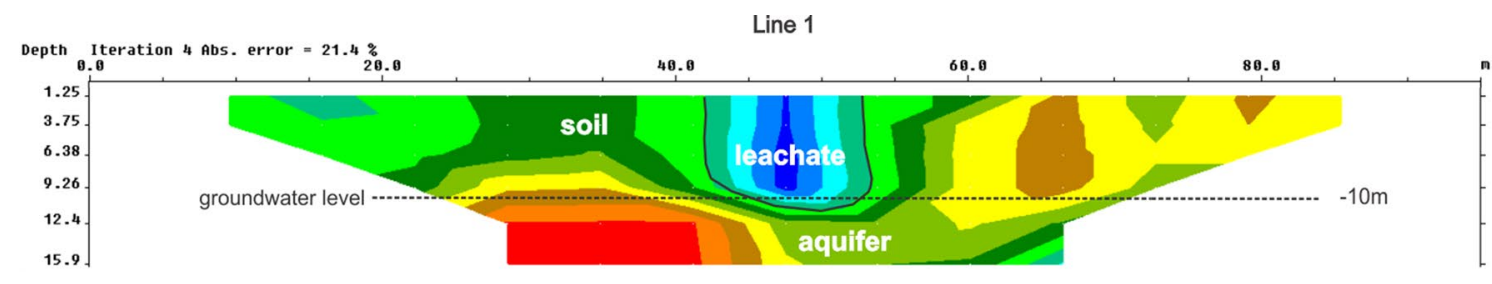

Line 5
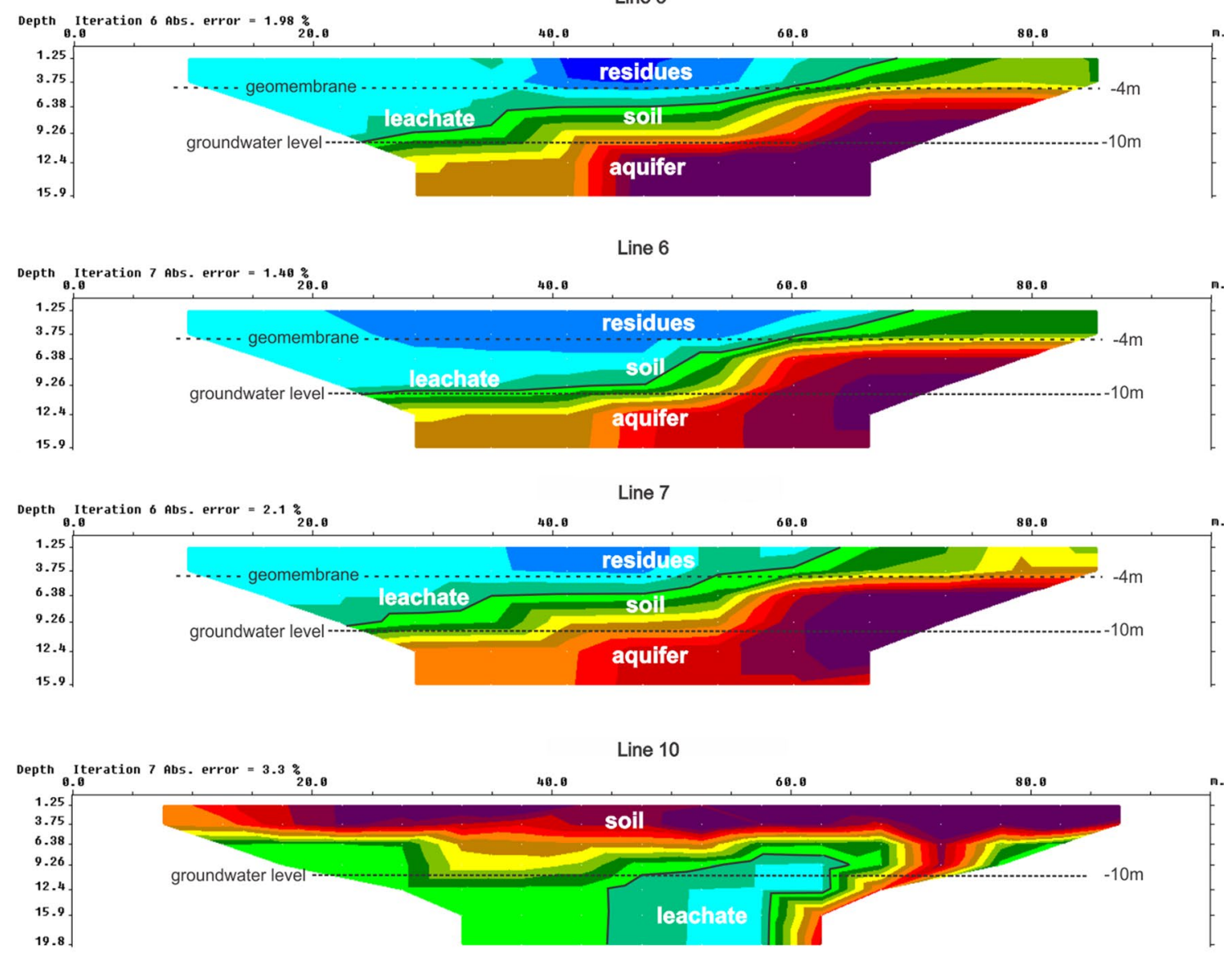

Line 11

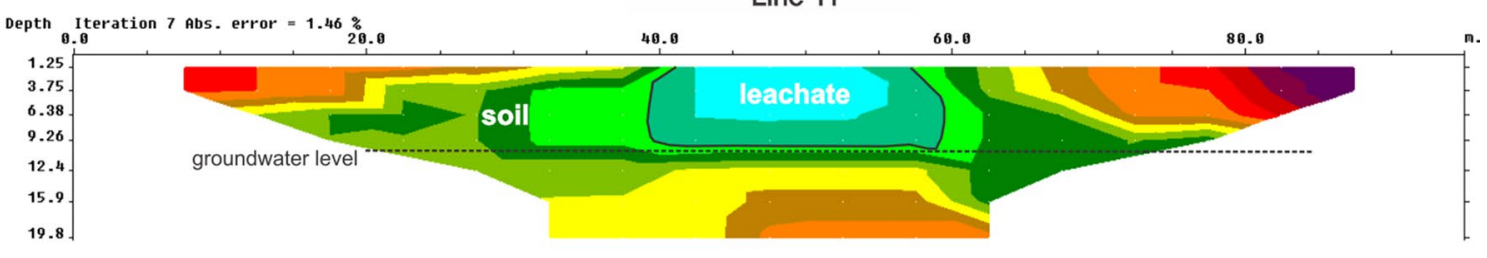

Line 12 - Reference

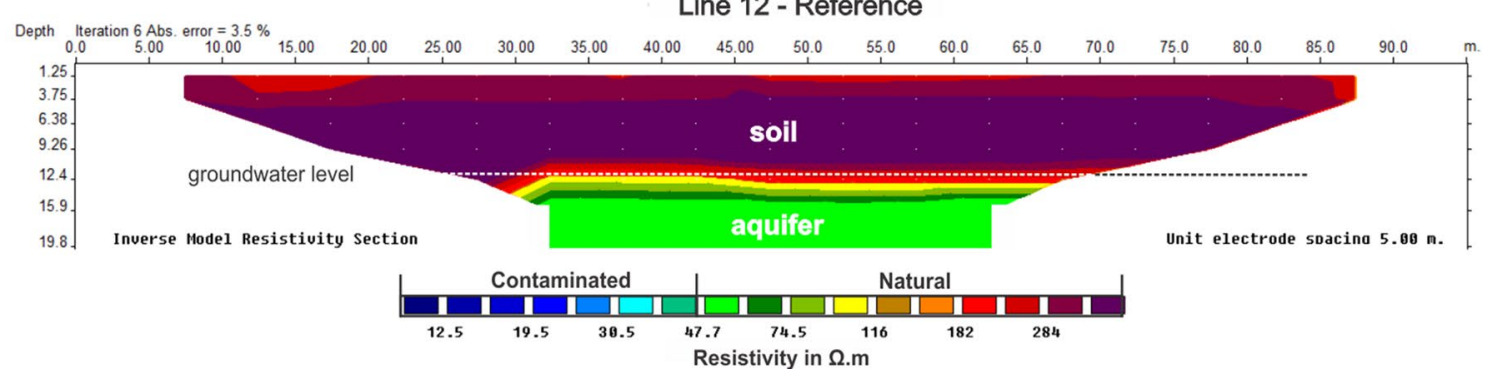


4Fig. 3 Representative inversion models of the study area, with the positioning of the groundwater and the geomembrane, beyond the limits of percolation of leachate based on the minimum value of resistivity described in the reference section

Viewed from above, the analysis shows a concentration of low resistivity values in the central portion of the cell, possibly due to the area's constructive profile, which uses the gravitational flow to direct the leachate to a drainage point (the two tanks placed at surface) below the waste cell (Fig. 2).

In an attempt to estimate the leachate's percolation points in the geomembrane, resistivity isosurface models were performed for a very low value, based on the hypothesis of high concentration of salts in places of concentrated flow. In this sense, from the bottom view of the interface, it is possible to check three conical morphology areas with $7 \Omega$ m resistivity, possibly related to the perforations in the geomembrane. The first area is positioned at the center of the cell and has the largest coverage of the three. The other two are smaller areas and are located in the northeastern side of the cell (Fig. 5).

The leachate percolation in the soil below the waste cell must result from the dispersion of the fluid and the dissolution of salts, with consequent increase in resistivity. The evolution of this process may result in the leachate's percolating vertically and reaching the aquifer.

This process can be noticed by the analysis of the model of the electrical resistivity at $-10 \mathrm{~m}$ depth, the horizon corresponding to aquifer's level. The analysis of this model shows a pattern where three points with resistivity around $14 \Omega \mathrm{m}$ occur, very similar to the points defined in the interface of the geomembrane (Fig. 5).

In relation to the position of these areas in the interface of the geomembrane, the two smaller areas of resistivity occur approximately $5 \mathrm{~m}$ toward the southeast, one of them with resistivity exceeding $14 \Omega \mathrm{m}$ and the other with reduced dimensions. This small displacement between the levels and reduced expression of these areas at the aquifer's level is indicative of the small quantity of leachate and of its natural weakening, besides an almost vertical flow on dry soil.

In this interface, the area of greatest scope also enables the modeling of a conical isosurface of $14 \Omega \mathrm{m}$, with flowing tendency toward the aquifer, placed at about $25 \mathrm{~m}$ southeast of the source of leakage in the geomembrane. This large displacement can be attributed to an expressive vector of horizontal flow, directly related to the groundwater flow.

The downstream monitoring well is positioned directly to the vector of flow from the area of larger scope and low resistivity. The results reveal alterations in all parametrical characteristic of the leachate's presence in the aquifer, with emphasis to a substantial increase in content of totally dissolved solids and to an increase in acidity.

\section{Conclusion}

Landfills are final depositories for solid waste, planned and implemented with the objective of minimizing environmental impacts. The leachate is an effluent liquid essentially characterized by high content of inorganically dissolved elements. Possible leakage points, at the geomembrane, in the bottom of sanitary landfills, must provide bottlenecks zones, with reduction in the speed of the leachate's gravitational flow in the interface, between the waste and the soil. Differences of salinity between the waste layer and the soil below allow the definition of the leakage zone by its low resistivity signature, under the perspective of electrical resistivity tomography data, whenever this parameter can be sampled in detail, as in this research.

The results of electric resistivity inversion models revealed lower values than the natural pattern for the area of study, which is characterized by low resistivity values, including the layer of waste as well as the soil and aquifer immediately below it.

The unification of $2 \mathrm{D}$ data results in $3 \mathrm{D}$ viewing models, allowing a comprehensive and integrated analysis. From resistivity maps ranging between -4 and $-10 \mathrm{~m}$, where isosurfaces of 7 and $14 \Omega \mathrm{m}$ were, respectively, modeled, three leakage points of leachate in the geomembrane and two points leachate's percolation in the aquifer were indicated. The low resistivity zones were recognized in the central portion of several 2D sections, whose interpolation resulted in

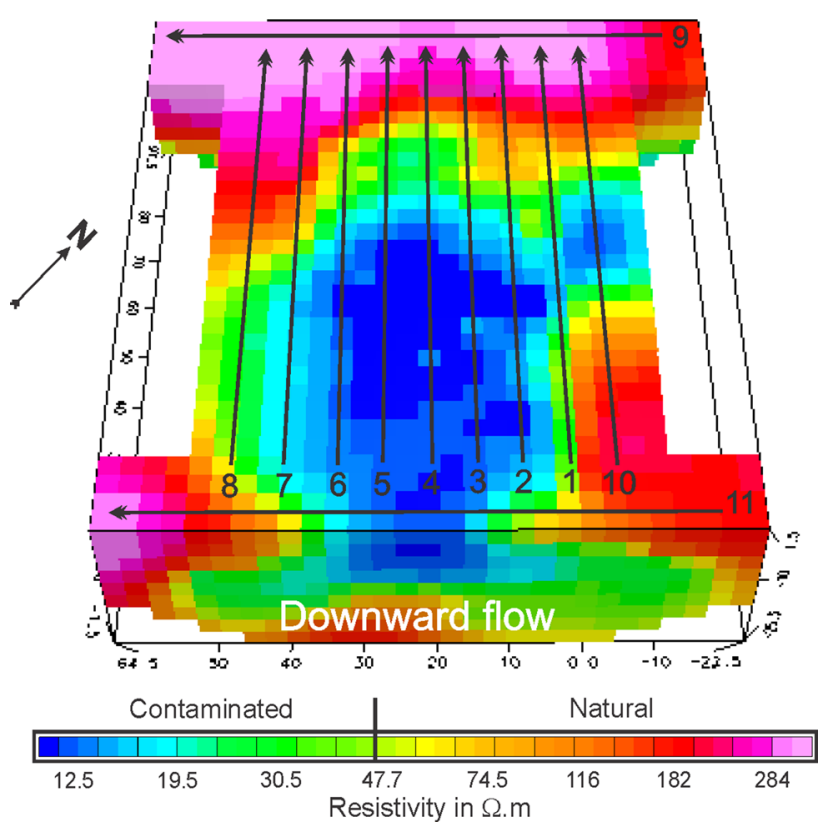

Fig. 4 3D block viewed from above, with direction following the groundwater flow and presenting the position of the electrical tomography lines 


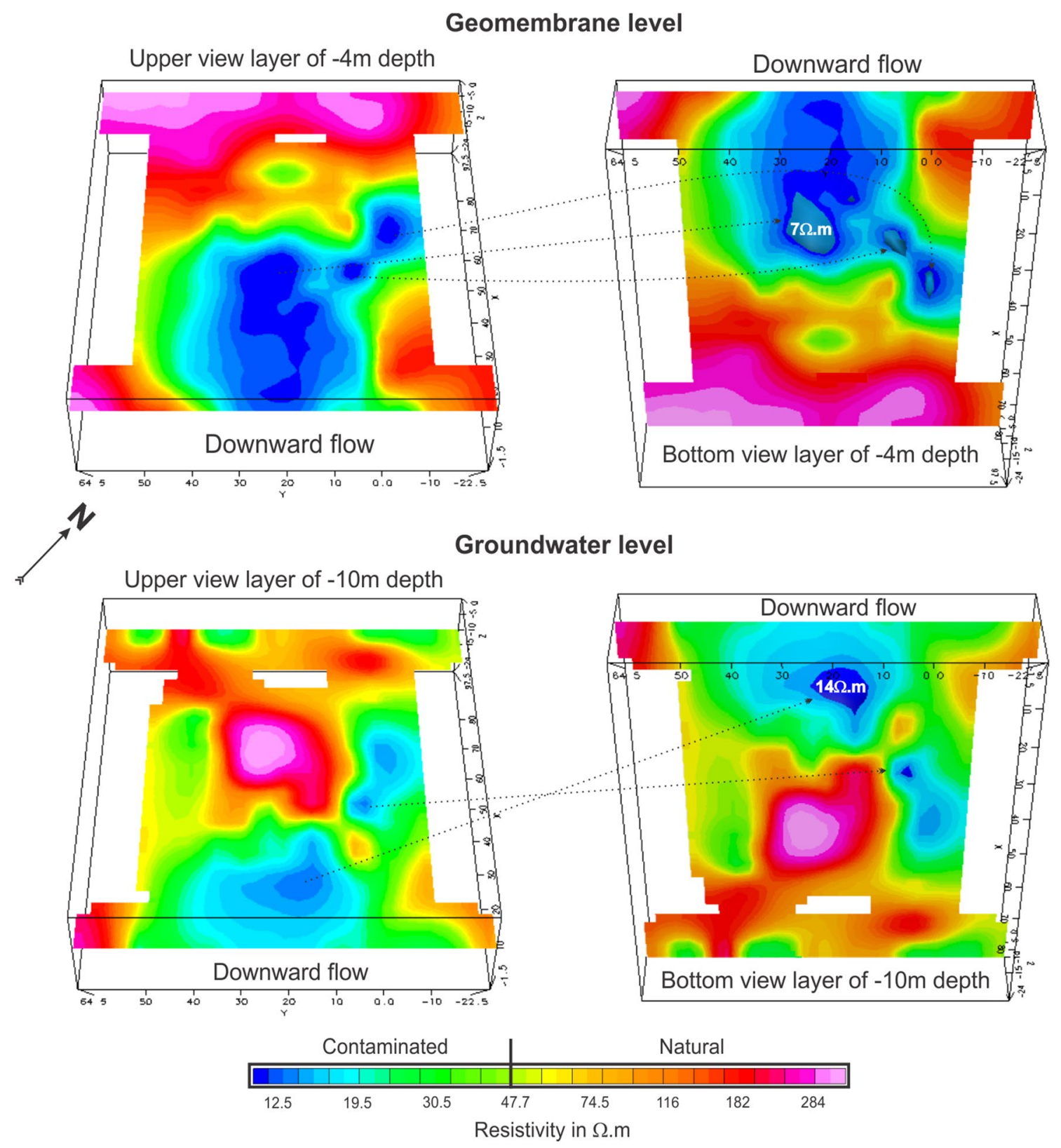

Fig. 5 Resistivity models for -4 and $-10 \mathrm{~m}$ depths, with isosurface modeling of 7 and $14 \Omega \mathrm{m}$ and points from above and below

a $3 \mathrm{D}$ visualization model with high probability of correspondence with reality, although it is possible to generate processing artifacts and deformations at the boundaries of the model.

The methodological proposal for the interpolation of 2D sections for the generation of $3 \mathrm{D}$ visualization models is a routine used in the estimation of reserves in mineral exploration, from geochemical data obtained in drillings, whose $3 \mathrm{D}$ modeling is adopted in the economic viability of mining projects and justifies the investment of millions of dollars In this sense, the integrated analysis of electrical resistivity in 3D models indicates a probable source of contamination in the landfill.

This study demonstrates the applicability of the electrical resistivity tomography method for environmental monitoring of landfills, which, despite all the planning involved in their construction, may present failures particularly related to the containment of leachate. Such failures in leachate containment can be detectable by indirect research tools and noninvasive techniques, which can also help the development of precise and inexpensive system for punctual remediation in particularly complex conditions. 
Procedures for traditional research, as the installation of monitoring wells on the landfill, presents the concentration of the contamination, but present severe limitations, in face of the possibility of new leakage points. Although the two investigations are important, ideally, whenever possible, the results must be presented as integration between the methods, so that the analytical data confirm the geophysical interpretations.

\section{References}

ABEM (2012) Terrameter LS-Instruction Manual. ABEM Instrument AB, Sundbyberg, p 122

ABRELPE (2014) Panorama dos resíduos sólidos no Brasil. Abrelpe, São Paulo, p 120

Aizebeokhai AP, Olayinka AI, Singh VS, Uhuegbu CC (2011) Effectiveness of 3D geoelectrical resistivity imaging using parallel 2D profiles. Int J Phys Sci 6:5623-5647

Belmonte-Jiménez S, Jimenez-Castañeda ME, Pérez-Flores MA, Campos-Enríquez J, Reyes-López JA, Salazar-Peña L (2012) Characterization of a leachate contaminated site integrating geophysical and hydrogeological information. Geofísica Int 51(4):309-321

Berkowitz B, Dror I, Yaron B (2014) Contaminant geochemistry-interactions and transport in the subsurface environment. Springer, Heidelberg, p 582

Bhandari A, Surampalli RY, Champagne P, Ong SK, Tyagi RD, Lo IMC (2007) Remediation technologies for soils and groundwater. American Society of Civil Engineers, Reston, p 441

Brasil (2007) Lei n. 11.445 de 2007-Política Nacional de Saneamento Básico. Governo Federal, Brasília

Brasil (2010) Lei n. 12.305 de 2010-Política Nacional de Resíduos Sólidos. Governo Federal, Brasília

Cempre (2013) Review. Cempre, São Paulo, p 24

Chambers JE, Kuras O, Meldrum PI, Ogilvy RD, Hollands J (2006) Electrical resistivity tomography applied to geologic, hydrogeologic, and engineering investigations at a former waste-disposal site. Geophysics 71:231-239

Christensen TH (2011) Solid waste technology \& management. Wiley, Chichester, p 1022

Côrtes ARP, Moreira CA, Veloso DIK, Vieira LB, Bergonzoni FA (2016) 528 Geoelectrical prospecting for a copper-sulfide mineralization in the Camaquã 529 sedimentary basin, Southern Brazil. Geofísica Int 55(3):107-117

Deublein D., Steinhauser A. (2011) Biogas from waste and renewable resources: an introduction. Wiley, Berlin, 2 ed., $572 \mathrm{p}$

Dono G De, Cardarelli E (2017) Tomography inversion of timedomain resistivity and chargeability data for the investigation od landfills using a priori information. Waste Manag 59:302-315

Elijah A, Oluwatosin LB (2015) Integrated geophysical and physicochemical assessment of Olushosu sanitary landfill site, southwest Nigeria. Arab J Geosci 8:4101-4115
Genelle F, Sirieix C, Riss J, Naudet V (2012) Monitoring landfill cover by electrical resistivity tomography on an experimental site. Eng Geol 145-146:18-29

Hernández-Soriano MC (2014) Environmental risk assessment of soil contamination. InTech, New York, p 905p

Jacobi PR, Besen GR (2011) Gestão de resíduos sólidos em São Paulo: desafios da sustentabilidade. Estudos Avançados 25(71):135-158

Kulikowska D, Klimiuk E (2008) The effect of landfill age on municipal leachate composition. Biores Technol 99:5981-5985

Lehr J, Hyman M, Gass TS, Servers WJ (2001) Handbook of complex environmental remediation problems. McGraw-Hill Handbooks, New York, p 606

Lema J, Mendez R, Blazquez R (1988) Characteristics of landfill leachates and alternatives for their treatment: a review. Water Air Soil Pollut 40:223-250

Loke MH, Baker RD (1996) Rapid least-squares inversion of apparent resistivity pseudosections by quasi-Newton method. Geophys Prosp 44:131-152

Maurya PK, Ronde VK, Fiandaca G, Balbarini N, Auken E, Bjerg PL, Christiansen AV (2017) Detailed landfill leachate plume mapping $2 \mathrm{D}$ and $3 \mathrm{D}$ electrical resistivity tomography-with correlation to ionic strength measured in screens. J Appl Geophys 138:1-8

Milsom JJ, Eriksen A (2011) Field Geophysics. Wiley, Chichester, p 297

Moreira CA, Lapola MM, Carrara A (2016) Comparative analyzes among electrical resistivity tomography arrays in the characterization of flow structure in free aquifer. Geofísica Int 55(2):119-129

Pawlowska M (2014) Mitigation of landfill gas emissions. CRC Press, Croydon, p 118

Porcher CA., Lopes RC. (2000) Programa levantamentos geológicos básicos do Brasil. Folha Cachoeira, Folha SH.22-Y-A. Estado do Rio Grande do Sul. Escala 1:250.000. Brasília, CPRM. 117 p

Reddy PJ (2011) Municipal solid waste management: processing, energy recovery, global examples. CRC Press, Boca Raton, p 470

Sara M. (2003) Site assessment and remediation handbook. $2^{\circ} \mathrm{ed}$., Lewis Publishers, Florida, $1161 \mathrm{p}$

SNIS-Sistema Nacional de Informações sobre Saneamento (2013) Diagnóstico dos Serviços de Água e Esgotos. Ministério das Cidades, Brasilia, p 432

Software Geotomo (2013) Rapid 2-D Resistivity \& IP inversion using the least-squares method-instructions manual. Geotomo, Gelugor, p 173

Twardowska I, Allen HE, Häggblom MH, Stefaniak S (2006) Soil and water pollution: monitoring, protection and remediation, Nato Science Series. Springer, Krakom, p 662

Valdalet P, Schmutz M, Pessel M, Franceshi M, Guérin R, Atteia O, Blondel A, Nogmseu C, Galaup S, Rejiba F, Bégassat P (2011) Mapping of contaminant plumes with geoelectrical methods. a case study in urban context. J Appl Geophys 75:738-751

Vieira LB, Moreira CA, Côrtes ARP, Luvizotto GL (2016) Geophysical modeling of the manganese deposit for Induced Polarization method in Itapira (Brazil). Geofísica Int 55(2):107-117

Yung-Tse H, Wang LK, Shammas NK (2014) Handbook of environment and waste management: land and groundwater pollution control, vol 2. World Scientific, Toh Tuck Link, p 1114 